\title{
Modern Composition and Distribution of Alien Fish Species in the Water Bodies of the Krasnoyarsk Territory
}

\author{
I. V. Zuev ${ }^{a, *}$, A. A. Vyshegorodtsev ${ }^{a}$, S. M. Chuprov ${ }^{a}$, and D. V. Zlotnik ${ }^{b}$ \\ ${ }^{a}$ Siberian Federal University, Krasnoyarsk, 660041 Russia \\ ${ }^{b}$ Federal State Budgetary Institution "Yeniseyrybvod," Krasnoyarsk, 660093 Russia \\ *e-mail:zuev.sfu@gmail.com \\ Received December 25, 2014
}

\begin{abstract}
This paper presents the information on the history of appearance, modern composition, and distribution of fish species that have been introduced by man or have settled independently in the water bodies of the Krasnoyarsk Territory since the early 20th century. It is shown that the fish fauna composition has expanded mainly in the basin of the upper and middle Yenisei as well as in the basin of the Chulym that is a right tributary of the $\mathrm{Ob}$; the fish fauna of the Pyasina and Khatanga rivers that are beyond the Arctic Circle has remained unchanged. Eleven fish species and two subspecies are new for the region; among them, common bream and sunbleak have largely expanded their range in the Yenisei and Chulym basins; pike perch, Amur sleeper, and bleak have enlarged their range only in the Chulym basin. The spread of other species is limited by the regions of their artificial stocking. Peled that is common for the northern regions of the territory was resettled in the Krasnoyarsk Reservoir; the status of Prussian carp that was introduced from the Amur River and degree of its assimilation with the local populations of this species are not clear.
\end{abstract}

Keywords: alien fish species, Krasnoyarsk Territory, Yenisei River, Angara River, Chulym River, Uzhur group of lakes

DOI: $10.1134 /$ S2075111716040123

\section{INTRODUCTION}

The modern Krasnoyarsk krai including the Taimyr and Evenkia has an extremely ramified hydrographic network, but a relatively small number of native fish and fish-like species (42 species). Since the 1930 s, the works on the directed formation of fish fauna at local lakes started in the south of the territory, and the hydrological construction in the second half of the century largely changed the regime of the upper and middle Yenisei as well as Angara. These factors have led to the situation that by the early 21st century invaders fish have begun to account for about a quarter of the species composition of the fish fauna in the territory.

The existing publications on the inventorying of the fish fauna of the region are usually limited to the scale of one river basin or its local area (Podlesnyi, 1958; Golovko, 1971; Kuklin, 1999; Vyshegorodtsev, 2000). The information about invaders is represented by a series of short articles, and there are no review papers on the subject.

The purpose of this paper is make a summary of the history of appearance, modern composition, and spread of alien fish species in the water bodies of Krasnoyarsk krai on the basis of our own research and retrospective analysis of scientific publications.
The description and counting of the number of alien and native fish species were carried out using their valid species names according to the "Vertebrates of Russia" (2014) information retrieval system of the Institute of Ecology and Evolution Problems Russian Academy of Sciences (IEEP RAS).

\section{THE PROPERTIES OF THE HYDROGRAPHIC NETWORK OF THE REGION}

The water bodies of the Krasnoyarsk krai belong to the basins of four major rivers: the Yenisei, Ob, Khatanga, and Pyasina. The greater part of the area of the region belongs to the basin of the Yenisei that is connected with the Angara-Baikal-Selenga system in the east. The watershed between the Yenisei and $\mathrm{Ob}$ basin goes along the western boundary of the region; moreover, in the area of the modern Krasnoyarskoe Reservoir, the width of the watershed that separates it from the Chulym that is a large Ob tributary is about $10 \mathrm{~km}$. The contact between the Yenisei and $\mathrm{Ob}$ basins (the $\mathrm{Ob}$-Yenisei channel) existed in the environs of the settlement of Aleksandrovskii shlyuz for a long time (Fig. 1b); today, it is not exploited. The basins of the Pyasina and Khatanga are located primarily beyond the Artic Circle and connected with others only through the Kara Sea and Laptev Sea. 


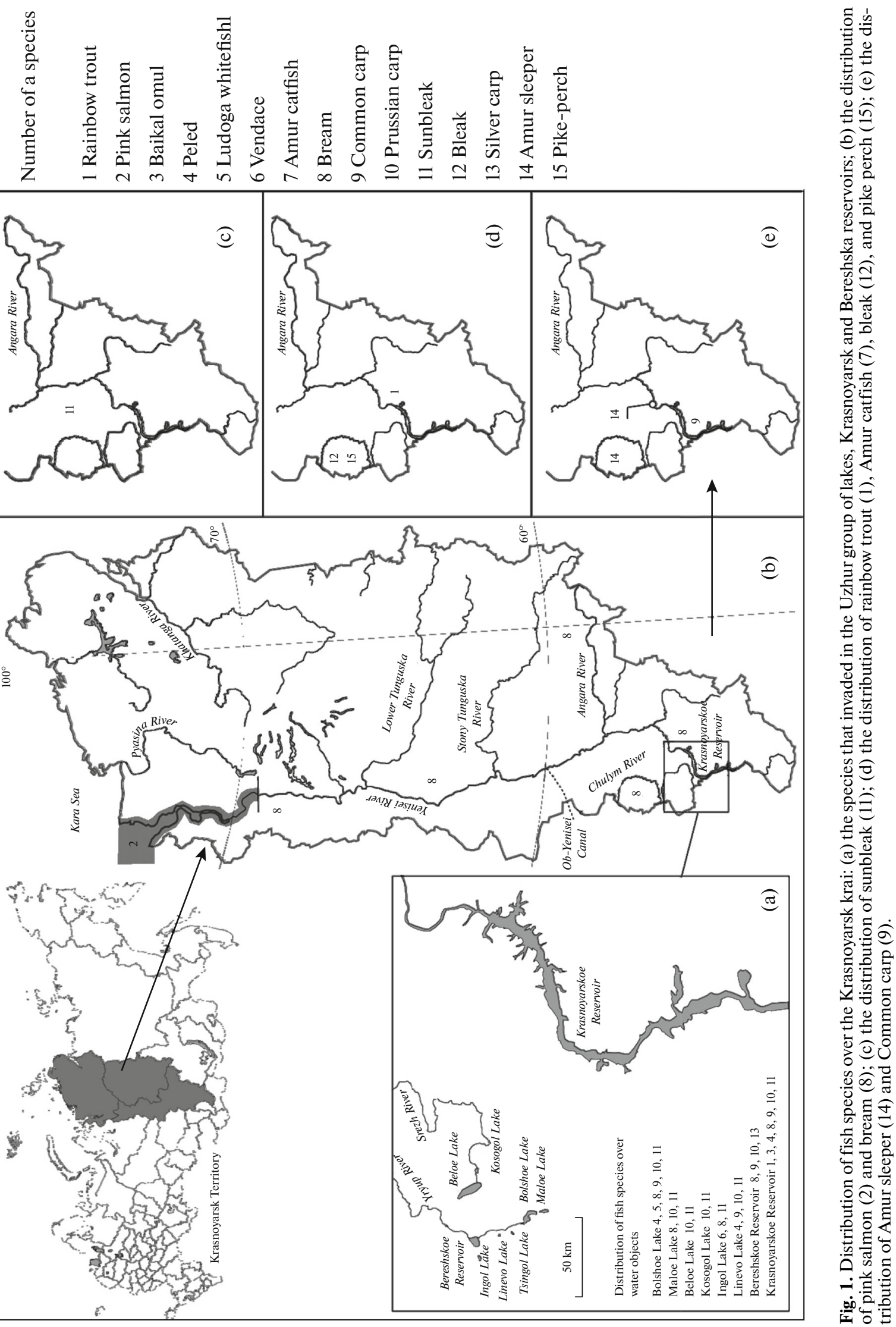


The 1960s brought about the beginning of largescale works on hydrological construction, which resulted in the cascade of hydroelectric power stations (HPSs) at the Yenisei: Sayano-Shushenskoe, Maina, and Krasnoyarsk HPSs. The cascade of the Angara reservoirs that were located in the Irkutsk oblast was complemented by the Boguchany HPS; the reservoir of the same name was filled to the normal water level $(208 \mathrm{~m})$ in 2015. The basin of the Chulym River became the place for organizing the Nazarovo and Berezovka State Regional Power Stations (SRPSs) that discharge warmed water into the Chulym and Beresha Reservoir, respectively. The construction of high-pressure HPSs at the Yenisei and Angara has changed not only the hydrological, but also the thermal regime of the rivers (Kosmakov et al., 2011). The Yenisei in the downstream of the Krasnoyarsk HPS does not freeze in winter over $100-300 \mathrm{~km}$ from the dam; the influence of the HPS on the ice regime of the river can be traced to the mouth of the Stony Tunguska River (Dolgikh and Shadrin, 2010).

The presence of a large Uzhur group of lakes in the southwest of the Krasnoyarsk krai that have a limited fish species composition and are devoid of typical plankton and benthophages has given large opportunities to increase their fish production by introducing valuable fish species, primarily whitefish (Ioganzen et al., 1972). It is this area that became a key center of aquaculture in the region in the 1930s. As a whole, the Uzhur group of lakes includes about ten water bodies with an area of more than $1 \mathrm{~km}^{2}$, which differ in size, depth, and salinity. The Bolshoe and Beloye lakes are the largest of them $\left(S=32.3 \mathrm{~km}^{2}\right.$ and $S=52.9 \mathrm{~km}^{2}$, respectively) (Fig. 1a). All lakes of this group belong to the Chulym River basin.

\section{SPECIFIC ESSAYS ON ALIEN FISH SPECIES}

\section{Rainbow Trout-Parasalmo (=Oncorhynchus) mykiss irideus (Gibbons, 1855)}

The cultivation of various forms of rainbow trout began at fish farms of the Krasnoyarsk krai and Republic of Khakassia since the 1980s. In this period, the Republic of Khakassia provided about a half of the commodity trout produced in Russia (Rostovtsev, 2000). Trout farms of the cage type operated at the Maina, Nazarovo, and Beresha reservoirs as well as in the non-freezing section of the tailrace of the Krasnoyarsk HPS. There were the cases of the unauthorized release of fish into the closed alpine lakes of the Sayany Mountains.

The long-term commercial cultivation of rainbow trout in a number of cage farms led to its fry going away to the reservoirs, Yenisei River, and its tributaries (Fig. 1d). The trout that escaped from cages has become the most numerous at the Maina Reservoir, which is a water body with a high water exchange rate; some individuals are found in the large tributaries (for example, the Abakan, Tuba, Amyl, etc.). Below the dam of the Krasnoyarsk HPS, trout was noted in the right-bank tributary of the Yenisei (the Mana River) as well as sporadically in the Yenisei at a distance of up to $200 \mathrm{~km}$ downstream from the city of Kransnoyarsk. The cases of spawning or finding trout fingerlings in natural habitats of the tailrace of the Krasnoyarsk HPS are unknown. The spread of trout down the Yenisei can be prevented by a permanent ice cover, in the presence of which the species does not survive (Mikheev, 1982).

\section{Pink Salmon- \\ Oncorhynchus gorbuscha (Walbaum, 1792)}

In 1959-1960, 29.6 mln salmon fingerlings with a weight of $0.2-0.7 \mathrm{~g}$ were released into the rivers of the Kola Peninsula (Burmakin, 1963). In 1963, salmon first appeared in the Yenisei River delta; subsequently, the species came to be regularly found in the catches in the lower Yenisei (Kuklin, 1999) (see Fig. 1b). There is a reason to believe that salmon spawns in the tributaries of the lower Yenisei, Tanama, Yar, and Dudinka. There is no official information on the population size and volumes of catches of this species.

\section{Baikal Omul- \\ Coregonus autumnalis migratorius (Georgi, 1775)}

The Uzhur group of the Upper-Chulym lakes and Krasnoyarsk Reservoir were stocked with the breeding material of Baikal omul (Fig. 1a). In 1970 and 1972, larvae of Baikal omul were released into the Bolshoe Lake at the amount of $3.3 \mathrm{mln} \mathrm{sp}$. and into the Tsingol Lake at the amount of $100000 \mathrm{sp}$. in order to obtain commodity products (Popkov, 1979). However, due to the lack of conditions for natural reproduction (the absence of large tributaries), the introduction of omul did not finish with naturalization.

From 1968 to 1969 , $6.75 \mathrm{mln}$ omul larvae were released into the Krasnoyarsk Reservoir. Since 1979, the reservoir has been stocked with its yearlings. For the period from 1991 to $2002,8.7 \mathrm{mln}$ sp. were released every year. The last release of fry was carried out in 2004 at the amount of $2.5 \mathrm{mln}$ sp. (Vyshegorodtsev and Zadelenov, 2013).

In the Krasnoyarsk Reservoir, the species is widespread throughout the water area and inhabits the pelagic zone at depths of 20-60 m. It is notable for a good growth rate, which is higher than in the maternal water body (the Baikal River). The species reaches sexual maturity at the age of 5-6 years (Vyshegorodtsev et al., 2005). The basis of the diet (95-98\% of the weight of a food bolus) is made up by a large copepod Heterocope borealis (Fisher, 1851), which was first found in 1974 in the near-dam section and later widely spread throughout the water area of the lower and middle sections of the reservoir (Skoptsov et al., 2003). The effectiveness of natural reproduction of omul in the reservoir is very low; its population is 
mainly limited by the volumes of stocking. The volume of catch was $8 \mathrm{t}$ in 2010 and $2.5 \mathrm{t}$ in 2011 (Vyshegorodtsev and Zadelenov, 2013).

\section{Peled-Coregonus peled (Gmelin, 1789)}

The natural area of peled in the Krasnoyarsk Territory is located in the water bodies and streams of the Khatanga and Pyasina River basins and in the Yenisei from the mouth to the Sym River (Podlesnyi, 1958; Vyshegorodtsev, 2000). There were repeated attempts to expand the range of the species by introducing it into the water bodies in the south of the region.

The stocking of the Krasnoyarsk Reservoir with peled larvae started in 1968 (Ol'shanskaya, 1975). For the period from 1968 to 2003 , more than $45 \mathrm{mln}$ larvae and fingerlings of peled were released into the reservoir (Vyshegorodtsev et al., 2005). The release of peled fry was renewed in 2007. The volume of the release for 2007-2009 was $11.3 \mathrm{mln} \mathrm{sp}$. The population of the species remains low and is determined by the amount of released fry to a greater extent than by natural reproduction. Before 2003, its catches fluctuated from 0.1 to $0.8 \mathrm{t}$. The volume of catch reached $18.1 \mathrm{t}$ in $2008,13.1 \mathrm{t}$ in 2009 , and $29.1 \mathrm{t}$ in 2015 (Godovoi otchet..., 2016). The calculated biomass of the fishing stock was $680 \mathrm{t}$ in 2014 (Gosudatsvennyi doklad..., 2015). Due to leaving the reservoir, peled also became fairly common in the catches of amateur fishermen in the tailrace of the HPS.

In the 1970s, peled eggs, larvae, and yearlings were released into the lakes that belong to the Uzhur group of the Upper Chulym lakes. The efficiency of introducing the species at the egg and larva stage was insignificant due to their extirpation by the native fish fauna (Gaidin and Burmakina, 2014). At present, the self-reproducing peled populations remain only in the Bolshoe and Linevo lakes (Fig. 1a).

\section{European Whitefish- Coregonus lavaretus (Linnaeus, 1758)}

The Uzhur lake group was at various times stocked with two forms of European whitefish from the Onega and Chud lakes: ludoga whitefish Coregonus ludoga Polyakov, 1874 and chud whitefish $C$. lavaretus maraenoides (Poljakow, 1874). At the time of introduction, they had the status of subspecies, which is reflected in the publications of that time (Bashmakov, 1953; Kolyadin, 1985).

Ludoga whitefish was first released into the Bolshoe Lake in 1931 and subsequently settled into other water bodies of the Uzhur lake group (Kolyadin, 1985) (Fig. 1a). The repeated introduction of 2.8 mln ludoga larvae was carried out from 1958 to 1974 (Kolyadin, 1985). The naturalization of the subspecies has taken place only in the Bolshoe Lake, although its population remains low.
Chud whitefish was brought into the Ingol Lake accidentally with spawn of other whitefish in 1939. Chud whitefish was not specially caught at the Ingol Lake. It was found as a bycatch in non-aqueous catches of vendace and rypus. The information on its commodity catches is only available for two years: the amount of catch was $0.09 \mathrm{t}$ in $1945(0.6 \%$ of the annual catch) and $0.41 \mathrm{t}$ in 1946 (12.2\% of the annual catch of all fish). At present, it is leant from amateur fishermen that whitefish is met very rarely, although there are no really confirmed findings for the last 6 years (Zlotnik, 2011).

\section{Vendace- \\ Coregonus albula (Linnaeus, 1758)}

In 1939, vendace was introduced into the Ingol Lake at the amount of $1 \mathrm{mln}$ eggs, which were brought from the Leningrad fish hatchery (Fig. 1a). The spawn was received as a rypus spawn, but turned out to be a mixed spawn of rypus, vendace, and whitefish (Bashmakov, 1953). It is just vendace that was quantitatively dominant in this lake in the 1950s. In the period from 1963 to 1966 , the lake was stocked with $10.5 \mathrm{mln}$ eggs of vendace from the Ilmen Lake, the catches of which in the Ingol reached 2.4 t per year in 1945-1950.

Nowadays, thanks to the protection measures that are related to giving the lake the status of a nature monument, vendace has become one of the dominants in quantity, whereas it was the scantiest species according to the data of 2001 (Zlotnik, 2013).

\section{Amur Catfish-Parasilurus asotus (Linnaeus, 1758)}

The information on the presence of catfish in the water bodies of the region is very scanty. The species was noted for the first time for the Yenisei basin by Kuklin (1999) who pointed to the emergence of Amur catfish in the Bratsk Reservoir. Subsequently, the presence of the species in the Angara reservoirs (Bratsk and Ust-Ilim reservoirs) was confirmed by Ponkratov (2013). Other information about catfish is represented only by oral reports on the catches of the species in the Angara River and sporadically in the lower Yenisei (Fig. 1d).

\section{Bream- \\ Abramis brama (Linnaeus, 1758)}

The introduction of bream into the Krasnoyarsk Reservoir was carried out as early as during the construction of the Krasnoyarsk HPS. In 1964 and 1966, 26200 different-age fish were released into the Yenisei (in the zone of the formation of the reservoir). Its reintroduction was regularly carried out in the next several years. The total amount of the introduced bream for the period from 1964 to 1970 was $37500 \mathrm{sp}$. (Ol'shanskaya et al., 1977). In the Krasnoyarsk Reservoir, bream is widespread throughout the water area. It 
lives in tributaries, bays, and in the shoreline zone of the reservoir itself. Some large specimens are caught at depths up to $35 \mathrm{~m}$ (Dolgikh and Skoptsov, 2005).

From the Krasnoyarsk Reservoir, bream went up to the upper Yenisei, settled in the water area of the Sayano-Shushenskoe Reservoir, and continues settling up along the Big and Small Yenisei. Some individuals go up by tributaries for hundreds of kilometers and even penetrate into deep oligotrophic lakes (Gundrizer et al., 1986).

The bream that went down through the dam of the Krasnoyarskaya HPS into the tailrace has become widespread in the middle Yenisei up to the Stony Tunguska. The species is sporadically met in the area up to the Dudinka (Fig. 1b). It is known in the major tributaries of the Yenisei (the Kan, Sym, and Angara). The species probably settled along the Angara from both the Yenisei and Bratsk Reservoir, into which it was introduced into in 1962-1971 (Ponkratov, 2013). Bream is particularly numerous in the Yenisei River in the section from the mouth of the Angara to the multiple Vorogovsk islands inclusively, in the feeding and spawning places of sturgeons, inconnu, omul, muksun, and many carp and perch fish species.

The appearance of bream in the Chulym River basin was preceded by its introduction into the Novosibirsk Reservoir and Upper Chulym lakes in 19571960 (Interesova, 2016). In the Chulym, the species has spread almost throughout the river; it is found in the Beresha Reservoir as well as in a number of lakes: the Bolshoe, Maloe, and Ingol Lakes (Fig. 1a).

In 2015, the total catch of bream in the water objects of the Krasnoyarsk krai was 152 t, including $46 \mathrm{t}$ in rivers, $0.2 \mathrm{t}$ in lakes, and $106 \mathrm{t}$ in reservoirs (Godovoi otchet..., 2016).

\section{Common carp-Cyprinus carpio Linnaeus, 1758}

In 1964-1968, common carp (carp) was introduced into the water bodies of the Koibalsk irrigation system (the Republic of Khakassia): the Sosnovoe, Podgornoe lakes, etc. The flood in 1966 destroyed a number of fish-breeding ponds at the Bidzha River, where common carp and Prussian carp were for the most part grown. All fish went downstream into the Yenisei River (Vyshegorodtsev et al., 2005). The species penetrated into the Krasnoyarsk and SayanoShushenskoe reservoirs.

The process of naturalization of common carp in the Krasnoyarsk Reservoir went rather slowly and took a long time. Common carp was registered for the first time in commercial catches in 1975-0.5 t (Vyshegorodtsev et al., 2005). The species adapted to the entire near-shore and littoral zone of the reservoir. The well warmed up areas in the upper and middle part of the reservoir are the main regions of its commercially significant concentrations. The official amount of the catch of the species in 2015 was about $8 \mathrm{t}$ (Godovoi otchet..., 2016).

Below the dam of the Krasnoyarsk HPS, common carp is found in the Yenisei River within precincts of the city of Krasnoyarsk. The species lives in the mouth of the Kan River; several sexually mature individuals were caught in the middle reaches of the Kan River near the confluence of its left-bank tributary Bolshaya Urya River (Fig. 1e). In the Chulym River basin, common carp is found in the Bolshoe and Linevo lakes, as well as in the Beresha Reservoir (Fig. 1a).

\section{Prussian Carp- \\ Carassius auratus gibelio (Bloch, 1782)}

In general, Prussian carp C. auratus (Linnaeus, 1758 ) is not alien to the water bodies of the Krasnoyarsk krai and was also noted as a independent species for the Yenisei basin in the summary of Podlesnyi (1958) without indicating the area of its distribution. In the Yenisei system, Prussian carp is met from the upper reaches to the basin of the Khantaika River (Vyshegorodtsev, 2000; Fauna pozvonochnykh..., 2004), lives in the floodplain and inland lakes of the lower Turukhan (Golovko, 1971; Golovko and Popov, 1973), and is known in the Khantaika Reservoir (Priroda..., 1988).

However, the works on the introduction of Prussian carp brought from the Amur River were carried out in the territory of the region and in the Irkutsk oblast in the 1960s. The species was introduced into the Bratsk Reservoir (Kuklin, 1999) and water bodies of the Uzhur lake group. In the period from 1960 to 1962 , about $7100 \mathrm{sp}$. of sexually mature carps were released into the Beloye Lake. In 1964-1966, the lake was stocked with other 4640 sp. of different-age Prussian carps and 420000 yearlings of this species from the ponds of the Uzhur fish hatchery (Zavyalova and Kolyadin, 1977). Ten years after the introduction, the annual catch of the species amounted to $259 \mathrm{t}$ (Kolyadin, 1981). Subsequently, the fish spread throughout the Chulym River system and penetrated into the Krasnoyarsk Reservoir.

Since the works on the morphological or molecular genetic identification of the native and introduced "forms" of Prussian carp were not carried out, it is impossible today to specify the boundaries of the spread of the Amur form and degree of its assimilation with the native populations of the species in the water objects of the region.

\section{Sunbleak-Leucaspius delineatus (Heckel, 1843)}

Sunbleak was for the first time indicated for Western Siberia in 1973 by professor G.M. Krivoshchekov as a random acclimatized species brought in summer 1962 to the ponds of the Oyashenskii carp hatchery (Novosibirsk oblast) from the Bryansk oblast together with carp (Kosolapov and Skalon, 2004). It is also 
known that sunbleak was accidentally imported (1965-1968) into the Kamenskii hatchery together with the stocking material from the ponds of the Kursk oblast. The fish spread from these hatcheries to the upper reaches of the $\mathrm{Ob}$ River and to the water area of the Novosibirsk Reservoir (Babueva et al., 1982; Kolyadin, 1985). The Chulym was entered by sunbleak from the Novosibirsk Reservoir. At present, the species is widespread throughout the Chulym basin, particularly in the floodplain and flowing water objects of the river, as well as in settling ponds and former coal pits.

In the basin of the upper and middle Yenisei, including the Angara and left-bank tributaries, sunbleak is found everywhere in mesotrohic and eutrophic water bodies as well as in some rivers (Fig. 1b). In a number of lakes and ponds, the species occupies a dominant position in abundance and biomass. Thus, the biomass of sunbleak came to about $30 \mathrm{~kg} / \mathrm{ha}$ in the small eutrophic Bugach Reservoir that is located within the precincts of the city of Krasnoyarsk (Zadorin et al., 2004). In the Krasnoyarsk Reservoir, the species was first found in August 2004 in the shoreline zone of the Syda Bay (Vyshegorodtsev et al., 2005).

\section{Bleak-Alburnus alburnus (Linnaeus, 1758)}

Bleak penetrated into the Chulym as a result of self-settlement from the Novosibirsk Reservoir, into which it got accidentally together with the stocking material during the fish intentional introduction in the period from 1957 to 1967 (Interesova, 2016). According to our data, the only boundary of the expansion of the species along the main line of the river is the dam of the Nazarovo SRPS, which is located at a distance of $1350 \mathrm{~km}$ from the mouth (Fig. 1d).

\section{Silver Carp- \\ Hypophthalmichthys molitrix (Valenciennes, 1844)}

The group of different-age fry of silver carp was introduced in 2002-2006 into the Beresha Reservoir (Zadelenov and Shchur, 2009), into which the heated water is discharged from the "Berezovska SRPS-2" (Fig. 1a). The purpose of the introduction was to suppress the mass blossoming of cyanobacteria in the water area of the reservoir. The species uniformly settled throughout the reservoir and was characterized by a satisfactory growth rate (Otchet..., 2005). In 2006, the official volume of catch was $0.13 \mathrm{t}$ (Godovoi otchet..., 2016). Nevertheless, the facts of natural spawning and presence of silver carp fry were not noted. At present, sexually mature individuals are sporadically met in catches of fishermen. Silver carp does not go beyond the limits of the reservoir into the Chulym River.

\section{Amur Sleeper-Perccottus glenii Dybowski, 1877}

The first appearances of Amur sleeper in the water bodies of the territory may be due to its settlement in the Ob basin. In the Tomsk oblast, the species was first found in 1990-1992, after which the researchers fixed its mass settlement in the middle part of the Ob basin, including the Chulym River basin (Reshetnikov and Petlina, 2007). In the next decade, Amur sleeper was repeatedly found by fishermen in the territory of the Achinsk region in the Chulym basin (Fig. 1e).

Amur sleeper formally appeared in the Yenisei basin as early as 2000, when it was fixed in the Upper Angara reservoirs, where it subsequently became a mass species (Demin and Kupchinskii, 2000; Ponkratov, 2013). However, the species was not found in other areas of the Angara River and directly in the Yenisei River. The assumption about the species living in the water bodies of the Stony Tunguska River basin was not confirmed (Reshetnikov, 2008).

Amur sleeper was first found in the water bodies of the middle reaches of the Yenisei in 2013 (Zuev and Yablokov, 2013). The control catch in the Bugach pond located within the precincts of the city of Krasnoyarsk resulted in catching different-size individuals of the species, including yearlings (Fig. 1e). The repeated surveys in 2013 confirmed its spread in both the Bugach pond and system of water bodies that are connected with it. Despite the fact that the distance of the pond from the channel of the Yenisei River is about $10 \mathrm{~km}$, there is no information about the presence of Amur sleeper directly in the river.

\section{Pike Perch- \\ Stizostedion lucioperca (Linnaeus, 1758)}

Pike perch spread in the Chulym River basin as a result of self-settlement from the Novosibirskoe Reservoir, into which it was repeatedly introduced from 1959 to 1964 (Interesova, 2016). The species is found in the lower and middle reaches of the river up to the Nazarovo SRPS dam, i.e., over about $1350 \mathrm{~km}$ from the mouth (Fig. 1d). The population is in a rather stable state, and pike perch fry was repeatedly noted in stomachs of pike.

The species is included into the category of valuable fish fauna species that make up the fishery fund within the Krasnoyarsk krai (Gosudarstvennyi doklad..., 2015). Since 2008, the catch of pike perch in the Chulym River has had official quotas at an amount of $0.2-1 \mathrm{t}$; however, the amount of the official catch is not high-less than $0.02 \mathrm{t}$ (Godovoi otchet..., 2016).

\section{CONCLUSIONS}

The presented data show that eleven fish species and two subspecies can be considered alien for the fish fauna of the Krasnoyarsk krai. The change in the species composition primarily involved the basins of the 
Yenisei (8 new taxons) and Chulym (9), and the fish fauna of the Pyasina and Khatanga Rivers that are beyond the Arctic Circle has remained unchanged.

The population of silver carp and rainbow trout is supported due to the fish being periodically introduced and their going away from cages; other species have formed self-reproducing populations. Bream and sunbleak that have widely settled in the Yenisei and Chulym basins have become the most successful among the naturalized species. Pike perch, bleak, and Amur sleeper are mass only in the Chulym. The spread of other species is limited by the regions of their artificial stocking. Peled and Prussian carp that are native for the region have expanded their range owing to migration from the northern areas to the southern ones (for peled) and introduction of the Amur form of crucian carp.

The history of the appearance of alien fish species in the water objects of the region also includes the numerous cases of official (Gaidin and Burmakina, 2014) and unsanctioned introductions, which did not finish with naturalization. In addition to the introduction of the species, which are popular in aquaculture (trout, peled, and carp), there were the cases of the introduction of broad whitefish and fry of pink salmon and chum salmon.

Directed introduction was the main vector of the appearance of alien species. In other cases (for Amur sleeper, sunbleak, Amur catfish, pike perch, and bleak), we can consider that the vector is due to the self-settlement from the neighboring regions, into which these species were introduced earlier purposefully or accidentally. In case of the Amur sleeper, which was caught in the ponds of the suburban zone of Krasnoyarsk, its introduction by aquarists is possible, since this species has not yet been found in the Yenisei itself.

The change in the hydrological regime of the Yenisei and Angara that was caused by the construction of HPSs was not the factor that determined the appearance of new species, but accelerated the naturalization of bream, common carp, and peled. The Nazarovo HPS dam at the Chulym River serves as a boundary for the spread of pike perch and bleak over the river, due to which they are found only in the downstream.

The main invasion corridors for self-settling species are the Angara River from the east and Chulym from the west. The Angara historically serves as a donor of the endemic Baikal fauna, which penetrates into the middle Yenisei. Thus, stone sculpin (Paracottus knerii) that is a Baikal cottidae species is found at a mass amount in the Yenisei in the area from Krasnoyarsk to the mouth of the Angara (Vyshegorodtsev, 2000). Several Baikal amphipods that are prevalent in the zoobenthos structure of the middle Yenisei have also penetrated in this place (Gladyshev and Moskvicheva, 2002; Andrianova, 2013). The Chulym River serves both for the penetration of alien fish species into the region from both the $\mathrm{Ob}$ basin within the Tomsk and Novosibirsk oblasts and for the spread of species introduced into the Uzhur lake group. The successive adaptation of invaders species to the Chulym River is due to the diversity of habitats in its basin, since there are a large number of additional water bodies along its main line. Despite the absence of a direct contact between the Yenisei and Chulym basins, we cannot exclude the potential displacement of some species by amateur fishermen in the region of the Krasnoyarsk Reservoir.

At present, there are no special programs of control over alien fish species in the water objects of the Krasnoyarsk krai. However, the annual assessment of permissible catches (APC) is made for some commercial invaders species (bream, common carp, and pike-perch) by the Scientific Research Institute of Ecology of Fishery Reservoirs that is a department institute of Russian Federal Fisheries Agency.

\section{ACKNOWLEDGMENTS}

The work was carried out within the state order of the Ministry of Education and Science of the Russian Federation to the Siberian Federal University, project no. 6.1089.2014/K.

\section{REFERENCES}

Andrianova, A.V., Dynamics of Yenisei zoobenthos evolution in the downstream of the Krasnoyarsk Hydroelectric Power Station, Vestn. Tomsk. Gos. Univ., Biol., 2013, no. 1 (21), pp. 74-88.

Babueva, R.V., Izotova, G.P., and Krivoshchekov, G.M., Leucaspius delineatus in the Karasuk River basin, in Opyt kompleksnogo izucheniya i ispol'zovaniya Karasukskikh ozer (Comprehensive Study of the Karasuk Lakes), Novosibirsk: Nauka, 1982, pp. 204-207.

Bashmakov, V.N., Naturalization of whitefish in the Great Lake and Ingol lakes in Krasnoyarsk krai, in Razvitie rybnoi promyshlennosti Zapadnoi Sibiri i problemy gidrobiologii (The Development of the Fishing Industry in Western Siberia and Problems of Hydrobiology), Tomsk: Tomsk. Gos. Univ., 1953, pp. 167-181.

Burmakin, E.V., Naturalization of freshwater fishes in the Soviet Union, Izv. Vses. Nauchno-Issled. Inst. Ozern. Rechn. Rybn. Khoz., 1963, vol. 53.

Demin, A.I. and Kupchinskii, A.B., Amur sleeper in Irkutsk Reservoir, Vestn. Irkutsk. Gos. S-kh. Akad., 2000, no. 19, pp. 9-10.

Dolgikh, P.M. and Skoptsov, V.G., The role of naturalized fishes in ichthyocenosis structure of the Krasnoyarsk Reservoir, in Vtoroi Mezhd. simp. po izucheniyu invaziin. vidov, "Chuzherodnye vidy v Golarktike (Borok-2)” Tezisy dokladov (The 2nd Int. Symp. on the Study of Invasive Species, "Alien Species in the Holarctic (Borok-2)," Abstracts of Papers), Borok, 2005, pp. 142-143.

Dolgikh, P.M. and Shadrin, E.N., Influence of the Angara-Yenisei Hydroelectric Power Station on aquatic bioresources and their habitats, in Mater. Zased. temat. soobshch. po problemam bol'shikh plotin i nauch. konsul'tativ. soveta Mezhvedomstv. ikhtiol. komissii "Rybok- 
hozyaistvennye problemy stroitel'stva i ekspluatatsii plotin i puti ikh resheniya" (Proc. Sess. of Thematic Community on the Problems of Large Dams and Scientific Advisory Council of Interdepartmental Ichthyology Commission: "Fisheries Problems of Construction and Operation of Dams and Their Solutions"), Moscow: World Wildlife Fund, 2010, pp. 68-71.

Fauna pozvonochnykh zhivotnykh plato Putorana (The Fauna of Vertebrates of Plateau Putorana), Romanov, A.A., Ed., Moscow, 2004.

Gaidin, S.T. and Burmakina, G.A., The history of fish farming in the Prienisejsky region (1931-1991), Vestn. Krasnoyarsk. Gos. Agrar. Univ., 2014, no. 12, pp. 254-262.

Gladyshev, M.I. and Moskvicheva, A.V., Baikal invaders have become dominant in the upper Yenisei benthofauna, Dokl. Biol. Sci., 2002, vol. 383, nos. 1-6, pp. 138-140.

Godovoi otchet o deyatel'nosti federal'nogo gosudarstvennogo byudzhetnogo uchrezhdeniya Eniseiskoe basseinovoe upravlenie po rybolovstvu i sokhraneniyu vodnykh biologicheskikh resursov za $2015 \mathrm{~g}$. (Annual Report on the Activities of the Federal State Budget Institution Yenisey Basin Fisheries Management and Conservation of Aquatic Biological Resources in 2015), Krasnoyarsk, 2016.

Golovko, V.I., Fishes of the Turukhan River, Extended Abstract of Cand. Sci. (Biol.) Dissertation, Tomsk, 1971.

Golovko, V.I. and Popov, P.A., Status of fish stocks of Lake Makovsky and the measures of their rational usage, in Vodoemy Sibiri i perspektivy ikh rybokhozyaistvennogo ispol'zovaniya (Reservoirs of Siberia and the Prospects for Fishery Usage), Tomsk: Tomsk. Gos. Univ., 1973, pp. 26-27.

Gosudarstvennyi doklad "O sostoyanii i okhrane okruzhayushchei sredy v Krasnoyarskom krae v 2014 g." (State Report "On the State and Environmental Protection in the Krasnoyarsk Krai in 2014”), Krasnoyarsk, 2015.

Gundrizer, A.N., Popkov, V.K., Vereshchinskii, E.G., Gundrizer, V.A., Konovalova, S.S., and Popkova, L.A., Biologicheskie osnovy povysheniya produktivnosti vodoemov Tuvinskoi ASSR (The Biological Basics for Improving the Productivity of Reservoirs in the Tuva ASSR), Tomsk: Tomsk Gos. Univ., 1986.

Interesova, E.A., Alien fish species in the Ob River basin, Russ. J. Biol. Invasions, 2016, vol. 7, no. 2, pp. 156-167.

Ioganzen, B.G., Petkevich, A.N., Votinov, N.P., Nesterenko, N.V., Podlesnyi, A.V., and Tironov, M.D., Akklimatizatsiya $i$ razvedenie tsennykh ryb $v$ estestvennykh vodoemakh $i$ vodokhranilishchakh Sibiri $i$ Urala (Naturalization and Breeding of Valued Fishes in Natural Waters and Reservoirs of Siberia and the Ural), Sverdlovsk: Sredne-Ural. Knizhn. Izd., 1972.

Kolyadin, S.A., Fishhusbandry in the Lakes of Uzhursk Group, in Tretya Kraev. konf. molodykh uchenykh i spetsialistov, posvyashchennoi XXVI s"ezdu KPSS “Okhrana $i$ ratsional'noe ispol'zovanie prirodnykh resursov Sibiri $i$ Dal'nego Vostoka”, Tezisy dokladov (The 3rd Reg. Conf. of Young Scientists and Specialists, Devoted to XXVI Congress of CPSU "Protecting and Managing of Natural Resources of Siberia and the Far East," February 17-19, 1981, Abstracts of Papers), Krasnoyarsk, 1981, pp. $155-157$.
Kolyadin, S.A., Ecological features of fish populations and possible formation of fish fauna in the lakes of Southern Krasnoyarsk krai, Extended Abstract of Cand. Sci. (Biol.) Dissertation, Irkutsk, 1985.

Kosmakov, I.V., Petrov, V.M., and Zadelenov, V.A., Influence of ice regime change of lower of the Krasnoyarsk Hydropower dams on Yenisei River to fish diversity in the river, Georisk, 2011, no. 1, pp. 32-36.

Kosolapov, M.Yu. and Skalon, N.V., Ichthyofauna of Belov and Oyashinsk areas of the Kemerovo region, Tr. Kuzb. Kompleks. Ekspedit., 2004, vol. 1, pp. 290-297.

Kuklin, A.A., Fish fauna of reservoirs of the Yenisei basin: changes due to anthropogenic impacts, Vopr. Ikhthyol., 1999, vol. 39, no. 4, pp. 478-485.

Mikheev, V.P., Sadkovoe vyrashchivanie tovarnoi ryby (Cage Breeding of Marketable Fish), Moscow: Legkaya Pishch. Prom., 1982.

Ol'shanskaya, O.L., The main features of the fish fauna formation of the Krasnoyarsk reservoir in period of its filling, in Biologicheskie issledovaniya Krasnoyarskogo vodokhranilishcha (Biological Researches in the Krasnoyarsk Reservoir), Novosibirsk: Nauka, 1975, pp. 147-155.

Ol'shanskaya, O.L., Vershinin, N.V., Tolmachev, V.N., Mikhaleva, T.V., Romanova, I.M., Volkova, N.I., and Eremeeva, G.G., Fishhusbandry of the Krasnoyarsk Reservoir, in Rybokhozyaistvennoe osvoenie vodokhranilishch Sibiri (Fishhusbandry Development in the Siberian Reservoirs), Leningrad: Gos. Nauchno-Issled. Inst. Ozern. Rechn. Rybn. Khoz., 1977, pp. 97-139.

Otchet o nauchno-issledovatel'skoi rabote "Monitoring "tsveteniya" vody vodokhranilishcha OAO "Berezovskaya GRES-1"” (Report on the Research Project "Monitoring of Water "Blooming" in Reservoir of the Berezovskaya Hydroelectric Power Station-1," no. 860), Krasnoyarsk, 2005.

Podlesnyi, A.V., Fishes of the Yenisei River, conditions of habitat and usage, Izv. Vses. Nauchno-Issled. Inst. Ozern. Rechn. Rybn. Khoz., 1958, vol. 44, pp. 97-178.

Ponkratov, S.F., Biological invasions of alien fish species into the basin of Angara reservoirs, Russ. J. Biol. Invasions, 2014, vol. 5, no. 1, pp. 38-44.

Popkov, V.K., Morphological and ecological characteristics and commercial importance of whitefish acclimatized in the lakes of the central part of the Altai-Sayan Highlands, Extended Abstract of Cand. Sci. (Biol.) Dissertation, Leningrad, 1979.

Priroda Khantaiskoi gidrosistemy (The Nature of the Khantaisk Hydroelectric Power Station), Ioganzen, B.G. and Maloletko, A.M., Eds., Tomsk: Tomsk Gos. Univ., 1988.

Reshetnikov, A.N., Has expansion of the fish rotan covered the Podkamennaya Tunguska river basin?, Tr. Gos. Prirod. Zapoved. Tungussky, 2008, no. 2, pp. 131-133.

Reshetnikov, A.N. and Petlina, A.P., Distribution of the fish rotan (Perccottus glenii Dybowski, 1877) in the Ob' River, Sib. Ekol. Zh., 2007, vol. 14, no. 4, pp. 551-556.

Rostovtsev, A.S., The rainbow trout industrial reproduction in Siberia, Extended Abstract of Doctoral (Biol.) Dissertation, Novosibirsk, 2000.

Skoptsov, V.G., Mikhaleva, T.V., and Evgrafov, A.A., Distribution of naturally acclimatized Heterocope borealis in the Krasnoyarsk Reservoir, in Mater. Mezhd. konf. 
"Troficheskie svyazi v vodnykh soobshchestvakh $i$ ekosistemakh" (Proc. Int. Conf. "Trophic Relations in Benthic Communities and Ecosystems”), Borok, 2003, pp. 118-119.

Vertebrates of Russia: Information and Search System, http://www.sevin.ru/vertebrates.

Vyshegorodtsev, A.A., Ryby Eniseya: Spravochnik (Handbook of Fishes in the Yenisei River), Novosibirsk: Nauka, 2000.

Vyshegorodtsev, A.A., Kosmakov, I.V., Anufrieva, T.N., and Kuznetsova, O.A., Krasnoyarskoe vodokhranilishche (Krasnoyarsk Reservoir), Novosibirsk: Nauka, 2005.

Vyshegorodtsev, A.A. and Zadelenov, V.A., Promyslovye ryby Eniseya (Commercial Fish Species of the Yenisei River), Krasnoyarsk: Sib. Fed. Univ., 2013.

Zadelenov, V.A. and Shchur, L.A., The impact of fish-sestofag white silver carp (Hypophthalmichthys molitrix) on phytoplankton condition in the Bereshsky Reservoir (Krasnoyarsk Territory), Vestn. Krasnoyarsk. Gos. Agrar. Univ., 2009, no. 8, pp. 89-97.

Zadorin, A.A., Zuev, I.V., and Vyshegorodtsev, A.A., Sunbleak (Leucaspius delineatus Heckel) as an invider species in the waterbodies of the krai, Biol. Vnutr. Vod, 2004, no. 1, pp. 75-79.

Zav'yalova, T.Ya. and Kolyadin, S.A., Changing of the fish fauna and fish productivity of the Beloe Lake due to goldfish naturalization, in Produktivnost' vodoemov raznykh klimaticheskikh zon RSFSR i perspektivy ikh rybokhozyaistvennogo ispol'zovaniya (Productivity of the Waters of Different Zones of RSFSR and the Perspective of Their Prospective Commerical Use), Krasnoyarsk, 1977, pp. 128-132.

Zlotnik, D.V., Current status of whitefish naturalized in some lakes of the Upper Chulym Group (Sharypovsky district, Krasnoyarsk krai), in Mater. II Mezhd. nauch. konf. "Raznoobrazie pochv i bioty Severnoi i Tsentral'noi Azii", (Proc. II Int. Sci. Conf. "Biodiversity of Soils and Biota of the North and Central Asia," Ulan-Ude, Russia), Ulan-Ude: Buryat. Nauch. Tsentr, Sib. Otd., Ross. Akad. Nauk, 2011, vol. 2, pp. 181-183.

Zlotnik, D.V., Ecological features of European whitefish Coregonus albula (Linnaeus, 1758), introduced into the Ingol Lake (Krasnoyarsk krai), in Mater. VIII Mezhd. nauchno-proizvod. konf. po biologii sigovykh ryb (Proc. VIII Int. Sci.-Pract. Conf. on Biology of Whitefish), Tyumen, 2013, pp. 98-103.

Zuev, I.V. and Yablokov, N.O., The first finding of rotan Perccottus glenii Dybowski, 1877 (Perciformes: Odontobutidae) in the waters of the Middle Yenisei, $\mathrm{Zh}$. Sib. Fed. Univ., Ser. Biol., 2013, vol. 6, no. 3, pp. 243-245.

Translated by L. Solovyova 